\title{
A seawater desalination scheme for global hydrological models
}

\author{
Naota Hanasaki $^{1,2}$, Sayaka Yoshikawa ${ }^{3}$, Kaoru Kakinuma ${ }^{3,4,5}$, and Shinjiro Kanae ${ }^{3}$ \\ ${ }^{1}$ National Institute for Environmental Studies, 16-2 Onogawa, Tsukuba, Japan \\ ${ }^{2}$ International Institute for Applied Systems Analysis, Schlossplatz 1, Laxenburg, Austria \\ ${ }^{3}$ Department of Civil and Environmental Engineering, Tokyo Institute of Technology, \\ 2-12-1-M1-6 O-okayama, Meguro-ku, Tokyo, Japan \\ ${ }^{4}$ Center for Climate Systems Research, Earth Institute, Columbia University, 2880 Broadway, \\ New York, NY, USA \\ ${ }^{5}$ NASA Goddard Institute for Space Studies, 2880 Broadway, New York, NY, USA \\ Correspondence to: Naota Hanasaki (hanasaki@nies.go.jp)
}

Received: 9 March 2016 - Published in Hydrol. Earth Syst. Sci. Discuss.: 31 March 2016

Revised: 25 August 2016 - Accepted: 16 September 2016 - Published: 12 October 2016

\begin{abstract}
Seawater desalination is a practical technology for providing fresh water to coastal arid regions. Indeed, the use of desalination is rapidly increasing due to growing water demand in these areas and decreases in production costs due to technological advances. In this study, we developed a model to estimate the areas where seawater desalination is likely to be used as a major water source and the likely volume of production. The model was designed to be incorporated into global hydrological models (GHMs) that explicitly include human water usage. The model requires spatially detailed information on climate, income levels, and industrial and municipal water use, which represent standard input/output data in GHMs. The model was applied to a specific historical year (2005) and showed fairly good reproduction of the present geographical distribution and national production of desalinated water in the world. The model was applied globally to two periods in the future (2011-2040 and 20412070) under three distinct socioeconomic conditions, i.e., SSP (shared socioeconomic pathway) 1, SSP2, and SSP3. The results indicate that the usage of seawater desalination will have expanded considerably in geographical extent, and that production will have increased by 1.4-2.1-fold in 2011-2040 compared to the present (from $2.8 \times 10^{9} \mathrm{~m}^{3} \mathrm{yr}^{-1}$ in 2005 to $\left.4.0-6.0 \times 10^{9} \mathrm{~m}^{3} \mathrm{yr}^{-1}\right)$, and 6.7-17.3-fold in 2041-2070 (from 18.7 to $48.6 \times 10^{9} \mathrm{~m}^{3} \mathrm{yr}^{-1}$ ). The estimated global costs for production for each period are USD $1.1-10.6 \times 10^{9} \quad(0.002-0.019 \%$ of the total global GDP), USD 1.6-22.8 $\times 10^{9}(0.001-0.020 \%)$, and USD 7.5$183.9 \times 10^{9}(0.002-0.100 \%)$, respectively. The large spreads
\end{abstract}

in these projections are primarily attributable to variations within the socioeconomic scenarios.

\section{Introduction}

Water is vital to society. However, due to population increases, economic growth, and climate change, there is growing concern over the sustainability of water use around the world. There have been a number of studies regarding present and future worldwide water availability and use. Initially, the mean annual runoff (i.e., river discharge) was regarded as the primary renewable water resource (Vörösmarty et al., 2000; Oki et al., 2001, 2003). With increasing sophistication of global hydrological models (GHMs), the sources of water have been subdivided into various categories, such as rivers, reservoirs, lakes, groundwater, and others (Hanasaki et al., 2008a, b; Wada et al., 2011; Wada and Bierkens, 2014; Döll et al., 2014).

In this study, we focused on desalinated water derived from seawater, which has not been explicitly represented as a water source in GHMs, except for a few cases. Desalination is a technique for removing high concentrations of minerals and salts from saline and brackish water. Although it accounts for a marginal fraction at present $\left(5.2 \mathrm{~km}^{3} \mathrm{yr}^{-1}\right.$ of the $3926 \mathrm{~km}^{3} \mathrm{yr}^{-1}$ total global water withdrawal in 2005 reported in the AQUASTAT database, http://www.fao.org/nr/ aquastat/), desalination may play a greater role in the future for several reasons. First, water demand is rapidly increasing 
in arid and semi-arid areas where precipitation is limited, and on some islands and cities with limited catchment areas. Desalination is a practical measure for providing freshwater to such areas because it is completely independent of the natural hydrological cycle. Second, due to rapid technological advances, the costs of production have dropped rapidly, making it competitive with traditional water resources (Bremere et al., 2001; Ghaffour et al., 2013; Ziolkowska et al., 2015). These two factors have encouraged the rapid installation of desalination plants globally (see Fig. S1 in the Supplement). Indeed, desalination is considered an adaptation measure for climate change for the freshwater sector (Jiménez Cisneros et al., 2014).

Desalinated water has been included in some previous global water resource assessments based on simulations. Oki et al. (2001) presented a global water resource assessment incorporating reported national desalinated water production for various countries. Oki et al. (2003) conducted future global water projections assuming that the present volume of desalination production would remain unchanged. As production of desalinated water is increasing rapidly, however, this assumption underestimates the future contribution of desalination. Wada et al. (2011) incorporated desalinated water as a water source in their GHM PCR-GLOBWB by spatially distributing the national volume of usage for areas within $40 \mathrm{~km}$ of the seashore. They assumed that the volume would increase in proportion to the population. The above examples represent reasonable simplifications for GHMs, but further refinement is necessary because desalination is increasing rapidly and is strongly connected to climate and socioeconomic conditions. Independently of GHMs, a few studies have projected future growth of desalination on a global scale. Bremere et al. (2001) projected the desalination capacity required for 10 water-scarce countries in 2025 to meet their growing municipal water demands. They assumed that water use per person would remain constant and that growth in municipal water demand would be proportional to population increase. Fichtner GmbH (2011) reported a detailed future projection of desalinated water production in the Middle East and north Africa (MENA). The projection shows marked increases in desalinated water production based on the assumption of rapid and widely distributed uptake of concentrating solar power desalination technology throughout the MENA region. Ouda (2014) projected future water supply and demand in Saudi Arabia under three scenarios, taking into account desalinated water and treated wastewater. Kim et al. (2016) proposed an economic approach to project future desalinated water production globally. The authors assumed that supply and demand of desalination is determined by price mechanisms, and reported that total desalinated water would reach $250 \mathrm{~km}^{3} \mathrm{yr}^{-1}$ at the end of the 21 st century. Further studies are needed to examine the effects of socioeconomic variables, such as growing water use per person, and to cover the whole globe because of the increase in areas where desalination is utilized.
In this study, we developed a model to infer the geographical distribution and production of seawater desalination. The model was designed to be incorporated into GHMs that are applicable for state-of-the-art global long-term projections. Because of the low specificity of GHMs (e.g., the typical spatial resolution is $0.5^{\circ} \times 0.5^{\circ}$ ), our model is primarily focused on regions where seawater desalination is used as much as conventional water sources such as river water and groundwater. It is beyond the scope of this study to reproduce or project individual desalination projects all over the world.

There were two key questions. First, what are the climatic and socioeconomic conditions where seawater desalination is implemented on a large scale around the world? Identification of such conditions would facilitate the development of a model to explain the present geographical distribution and production of seawater desalination. Second, what would be the production of desalinated water in the future under various socioeconomic scenarios? The model was developed and validated utilizing newly available global datasets. Future projections were conducted based on a comprehensive global water assessment (Hanasaki et al., 2013a, b). Both the distribution and production of seawater desalination were assessed for three socioeconomic scenarios to meet increasing industrial and municipal water requirements.

This paper is structured as follows. Section 2 describes the data, model, and simulation settings. In Sect. 3, the results of the model and simulation are presented along with a discussion regarding its performance in reproducing the present distribution of desalination plants. The results of future projections are also shown. Section 4 concludes the paper.

\section{Methods}

\subsection{Desalination data}

We first collected country-based information on desalination production for nine countries with the largest seawater desalination capacity in the world from the AQUASTAT database: United Arab Emirates (UAE), Saudi Arabia, Kuwait, Spain, Qatar, Libya, Bahrain, Israel, and Oman (hereafter "major countries"). We selected the year 2005 as the base year mainly due to the availability of socioeconomic data as discussed below. In addition, we collected municipality-based information for Saudi Arabia (KICP, 2011) and the UAE (RSB, 2013). In spite of our efforts, subnational information for other countries was not found.

To obtain spatially detailed data, we used DesalData (http: //www.desaldata.com/). As of 2014, DesalData included data for 17335 individual desalination plants around the world. The total capacity of desalination reached $31.4 \mathrm{~km}^{3} \mathrm{yr}^{-1}$ globally from all water sources. Individual records contain data such as plant status, source water type, user category, plant size, and geographical location (longitude and latitude). Note that plant size shows the capacity of plants, not the ac- 
tual production. The ratio between the capacity and production varies by project.

Since the objective of this study was to develop a model that would be applicable to the global domain for long-term water scarcity projections, we focused on information regarding active major plants using seawater as source water. Currently, seawater is the primary source of desalination, amounting to $19.2 \mathrm{~km}^{3} \mathrm{yr}^{-1}$, followed by brackish water, saline inland and river water, and others. First, we selected the major desalination plants to be included in our analyses. The detailed selection criteria and the rationale are shown in Table S1 and the Supplement. Next, we selected 613 large plants using seawater as the water source. We examined the list of plants and excluded records if necessary. For example, DesalData contain some records indicating that plants in inland regions use seawater as the source, which is erroneous. A total of 54 plants were excluded from this study. These are listed in Table S2 with the reasons for their exclusion. Finally, we used a total of 559 large plants using seawater as the water source (hereafter "major plants"). Although this is less than $4 \%$ of total records (559 out of 17335), as shown in Table S3, these plants account for $81 \%$ of the total capacity of active seawater desalination plants $\left(12.7 \mathrm{~km}^{3}\right.$ out of $15.7 \mathrm{~km}^{3}$ ). The number of plants and their total capacity are summarized in Table S3.

To determine the distances between desalination plants and major cities of selected countries, the geographical data of major cities were collected. We referred to the GeoNames database (http://www.geonames.org), which reports the geographical locations and populations of major cities around the world. We selected cities with populations larger than 100000 (hereafter "major cities").

\subsection{Hydrometeorological data}

At present, major plants are located mostly in arid regions. This makes sense because alternative water sources are limited in such conditions and costly seawater desalination becomes a practical option. To express aridity, the ratio of precipitation to potential evapotranspiration (hereafter aridity index, AI) was calculated globally. We used the WATCH Forcing Dataset (Weedon et al., 2011) as a global meteorological dataset for the historical period in question. This dataset covers the whole globe at a spatial resolution of $0.5^{\circ} \times 0.5^{\circ}$ and includes basic meteorological variables at $6 \mathrm{~h}$ intervals, i.e., precipitation, air temperature, specific humidity, wind speed, air pressure, and shortwave and longwave downward radiation. Using the data from 1971 to 2000, we calculated the mean annual precipitation and potential evapotranspiration for each grid globally. The latter was calculated using the H08 global hydrological model (Hanasaki et al., 2008a, b).

For the future period, we used the climate projections obtained with a global climate model (GCM), namely MIROC4-ESM-CHEM. The selection and combination of the GCM and climate scenarios and the methods of downscaling and bias correction were identical to those reported previously (Hanasaki et al., 2013a, b).

\subsection{Socioeconomic data}

For population and GDP, we referred to the shared socioeconomic pathways (SSPs) database provided by IIASA (https://secure.iiasa.ac.at/web-apps/ene/SspDb), which covers both the historical (1980-2005) and future periods (20052100) for 203 nations. The data for future periods came from model-based projections under five distinct socioeconomic views, i.e., SSP1 (sustainability), SSP2 (middle of the road), SSP3 (fragmentation), SSP4 (inequality), and SSP5 (conventional development; O'Neill et al., 2014). GDP is shown in purchasing power parity (PPP) in 2005 US dollars (USD). This means that both monetary inflation over time and differences in price among nations or regions are removed from the GDP projections in this study.

For nationwide water use data, including desalinated water production, we relied primarily on the AQUASTAT database for the historical period in question. This database includes municipal and industrial water use data for 200 nations from 1960 to 2010 at 5-year intervals. Data are available for most countries in 2000 or 2005 but are largely missing for other years. For the future period, we used the projections of Hanasaki et al. (2013a). They estimated water withdrawal for irrigation, industrial, and municipal use over three periods (2011-2040, 2041-2070, and 2071-2100, centered on 2025, 2055, and 2085, respectively). Projections of industrial and domestic water withdrawal were obtained with a semiempirical model using electricity production and population as primary driving forces and scenario-based parameters of improvements in water use efficiency. The parameters were set to be compatible with the storylines of the SSPs (e.g., slow improvements in SSP3, rapid improvements in SSP1). Consequently, as shown in Figs. 12 and 14 of Hanasaki et al. (2013a), the projected future water withdrawal was largest in SSP3 and smallest in SSP1. Note that these projections are demand based without specifying water sources. The key socioeconomic factors are summarized in Table 1. In this study, we focused on three scenarios, i.e., SSP1, SSP2, and SSP3.

\subsection{Analyses of collected data}

In this subsection, the collected data are analyzed to model seawater desalination around the world. We quantitatively investigate desalination production and usage at the national and subnational levels. Because seawater desalination is mainly used in coastal arid regions, aridity conditions and distances from the seashore to plants and cities are also examined.

Table 2 summarizes desalinated water capacity and production in the major countries. The countries accounted for $85 \%$ of the seawater desalination plant capacity in 2005 
Table 1. Global future scenarios in 2055 (extracted from Hanasaki et al., 2013a, b).

\begin{tabular}{lrrrrrrr}
\hline Item & 2005 & 2025 SSP1 & SSP2 & SSP3 & 2055 SSP1 & SSP2 & SSP3 \\
\hline Radiative forcing & - & RCP2.6 & RCP4.5 & RCP6.0 & RCP2.6 & RCP4.5 & RCP6.0 \\
Global mean temperature rise (K) & 0 & 1.7 & 1.5 & 1.4 & 2.4 & 2.9 & 2.9 \\
Population $\left(10^{9}\right.$ people) & 6.5 & 7.4 & 7.8 & 7.9 & 8.5 & 9.3 & 10.3 \\
GDP $\left(10^{12} \mathrm{USD}\right)$ & 56 & 88 & 84 & 79 & 319 & 255 & 186 \\
Municipal water withdrawal $\left(\mathrm{km}^{3} \mathrm{yr}^{-1}\right)$ & 446 & 544 & 599 & 632 & 622 & 823 & 936 \\
Industrial water withdrawal $\left(\mathrm{km}^{3} \mathrm{yr}^{-1}\right)$ & 724 & 853 & 1169 & 1436 & 520 & 1437 & 1895 \\
\hline
\end{tabular}

UAE and Saudi Arabia produced the largest volumes of desalinated water, which accounted for more than half of the global total. The major countries share two characteristics. First, all are located in the Middle East or on the coast of the Mediterranean Sea and have arid or semi-arid climates. Second, their income is relatively high: GDP per person exceeds 14000 USD PPP person ${ }^{-1} \mathrm{yr}^{-1}$.

Next, we focused on water use in the major countries, as shown in Table 2. More than 3 times the volume of water was used by municipalities than by industry, except in Spain. Globally, $99 \%$ of major plants were installed for combined municipal and industrial use, with $90 \%$ for municipal water use. Seawater desalination was seldom used for agricultural water supply. The production to capacity ratio varied considerably among nations, ranging from 53 to $110 \%$; the ratio sometimes exceeded $100 \%$, probably due to inconsistencies in the data and the year of report.

Figure 1 shows the geographical distributions of major plants in the Mediterranean and Middle East regions where the majority of plants are concentrated. Note that the plants were aggregated into gridded data with a spatial resolution of $0.5^{\circ} \times 0.5^{\circ}$ for consistency with the final simulation. As clearly shown in the figure, the major plants were mainly located on the seashore and near large cities.

Figure 2 shows the AI of the present climate. Among the major countries, countries located in the Arabian peninsula, namely UAE, Saudi Arabia, Kuwait, Qatar, Bahrain, and Oman, are located in a hyper-arid climate, where the AI is below 0.15 . The countries on the coast of the Mediterranean Sea, namely Spain, Libya, and Israel, are located in more humid climates than the above-mentioned countries, with AIs typically between 0.15 and 0.5 . Note that the desalination plants in Spain are only located on the southeastern coast and some islands where the AI is substantially lower than that in the remaining regions. The fraction of desalinated water production to total industrial and municipal water withdrawal is shown in Table 2. The fraction for the countries in the Arabian peninsula exceeds $50 \%$ except for Saudi Arabia, while that for the Mediterranean countries falls below $20 \%$. This indicates that desalinated water is a major water source for industrial and municipal water in countries in the Arabian peninsula, while it is supplemental in the countries on the Mediterranean Sea.
We plotted the relationship between the AI and plant capacity in each grid cell (Fig. S2), which shows a remarkable difference in the distribution of capacity by AI. We applied the segmented regression method and estimated the break point at $\mathrm{AI}=0.082$.

Figure 3 shows the distances of the major desalination plants from the seashore and the primary cities of the major countries. Desalination plants are typically located on the seashore supplying water to cities at close range. Therefore, we considered that the summation of the distance between the seashore and a plant, and that from the plant to the closest major city was the distance that seawater was transferred. We calculated the distance using the Clark Lab's IDRISI Taiga Release 16.05 GIS platform software (Eastman, 2009). Note that due to technical limitations of the software, the individual plants were first aggregated into $5 \operatorname{arcmin} \times 5 \operatorname{arcmin}$ grid cells, and then the distance was estimated at intervals of $1 \mathrm{~km}$. We analyzed seven of the major countries including cities larger than 100000 persons. The results indicated that $90 \%$ of the major desalination plants were located within $15 \mathrm{~km}$ from the seashore and $170 \mathrm{~km}$ from major cities. Taking the distance from the coastline and cities into account, the area using seawater desalination extended approximately $170-185 \mathrm{~km}$ (roughly corresponding to the edge $(165 \mathrm{~km})$ and diagonal $(233 \mathrm{~km})$ of $3 \times 3$ grid cells with a spatial resolution of $0.5^{\circ} \times 0.5^{\circ}$ ) from the seashore.

For further geographical breakdown, Table 3 shows the water supply of the major cities in UAE and Saudi Arabia. The two largest cities in UAE, Abu Dhabi and Dubai, depend heavily on desalinated water. Municipal and industrial water for Abu Dhabi is supplied entirely by desalinated water (EAAD, 2012) and their plant capacity reaches $1.18 \times 10^{6} \mathrm{~m}^{3} \mathrm{day}^{-1}$. Information on detailed water supply in Dubai was not available, but a news article suggested that $98.8 \%$ of Dubai's water is supplied by desalination (Hackley, 2013). The total desalinated water production for the six cities in Saudi Arabia shown in Table 3 accounted for $80 \%$ of the national desalinated water supply. For these cities, desalinated water accounted for as much as $69 \%$ of the total supply. The sources of water varied between cities and regions. Jeddah, Makkah, Al Taif, and Al Madinah were largely dependent on desalinated water. Here, we note two exceptional cities. Although located $450 \mathrm{~km}$ from the seashore, Riyadh 


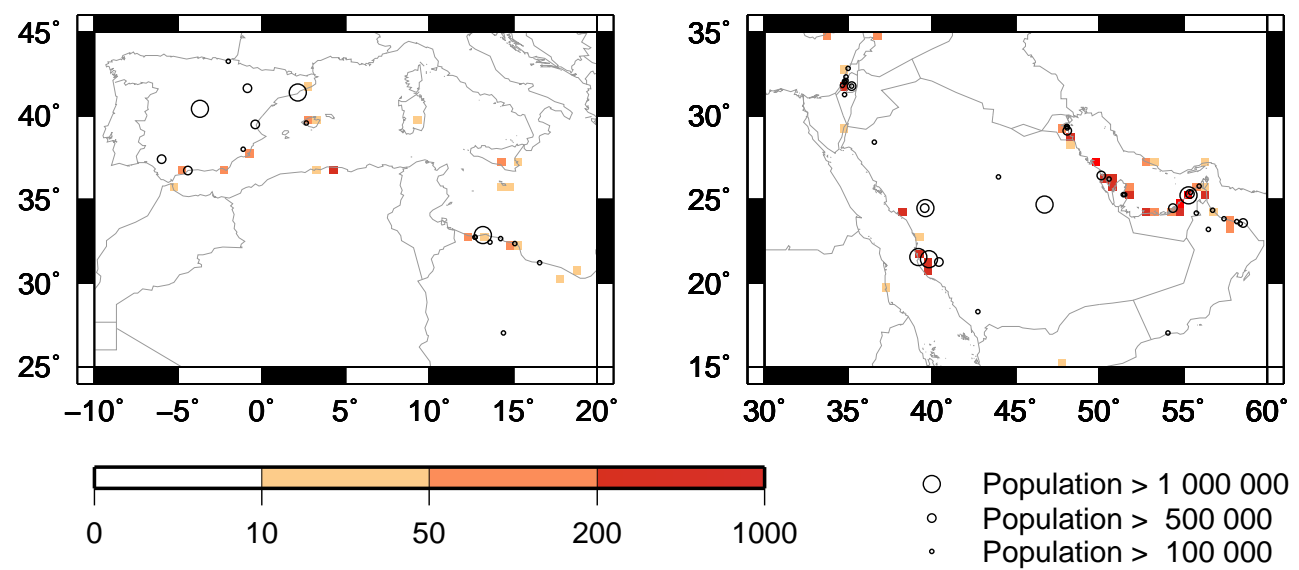

Figure 1. Actual locations of major desalination plants in the Mediterranean and Middle East in 2005. Boxes and circles represent plants (in $1000 \mathrm{~m}^{3}$ day $^{-1}$ of capacity; DesalData) and major cities (GeoNames), respectively.

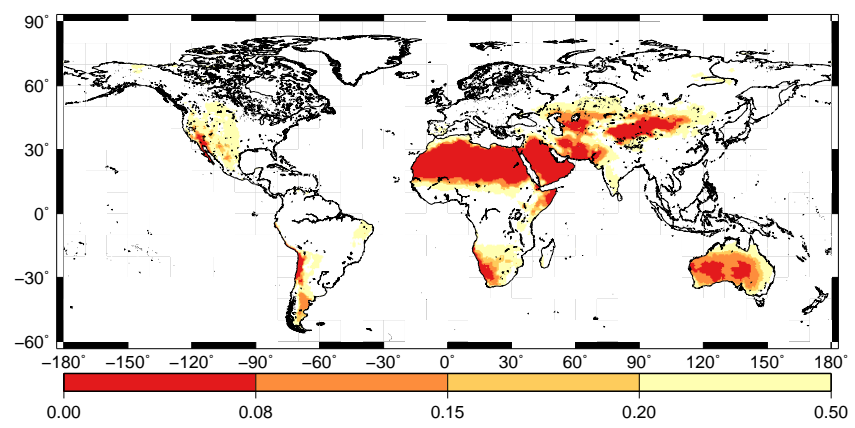

Figure 2. Simulated aridity index under the present climate (ratio of precipitation to potential evapotranspiration).

obtains about half of its water from seawater desalination transferred via pipeline. In contrast, although located on the seashore, Dammam depends on seawater desalination for less than $50 \%$ of its water supply.

\subsection{Seawater desalination model}

We developed a seawater desalination model (SDM) to estimate the areas where desalinated water is used and the volume of desalinated water production. As the model is intended to be incorporated into the global water resources model H08 (Hanasaki et al., 2008a, b), for consistency, its spatial resolution was set at $0.5^{\circ} \times 0.5^{\circ}$.

SDM consists of a set of climatological, geographical, and socioeconomic conditions to estimate the spatial extent of where seawater desalination is likely to be used. SDM identifies the grid cells in which all of the conditions given below are met. We called these grid cells area utilizing seawater desalination (AUSD) cells. In the AUSD grid cells, fresh water is produced by seawater desalination technology and used to meet local water demands under several assumptions. By combining the gridded map of AUSD cells and requirements (a) From coast

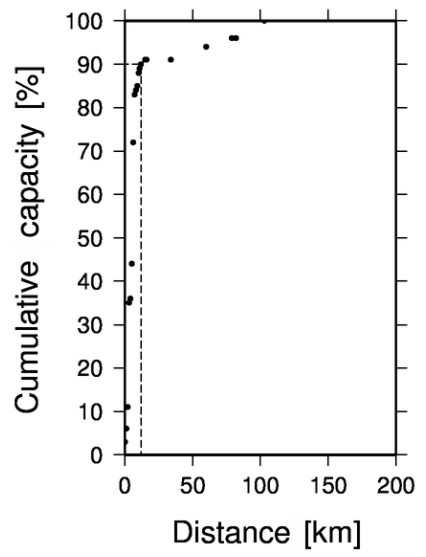

Figure 3. Cumulative capacity of desalination water and the distance of plants from the coastline (a) and major cities (b). The broken line shows the 90th percentile.

for water withdrawal (i.e., potential water demand), which is standard input/output data of global hydrological models, we can estimate the global production of seawater desalination. Note that AUSD cells indicate where desalinated water is used and, hence, they are not identical to the location of individual desalination plants. It is expected that the spatial extent of AUSD cells includes the locations of major seawater desalination plants, but desalination plants are not necessarily located at every AUSD grid cell because desalinated water can be transferred to surrounding grid cells through the pipeline network. The conditions and assumptions of SDM were determined based on analyses of the national and subnational statistics of desalinated water production and the geographical distribution of desalination plants, as described in Sect. 2.4 


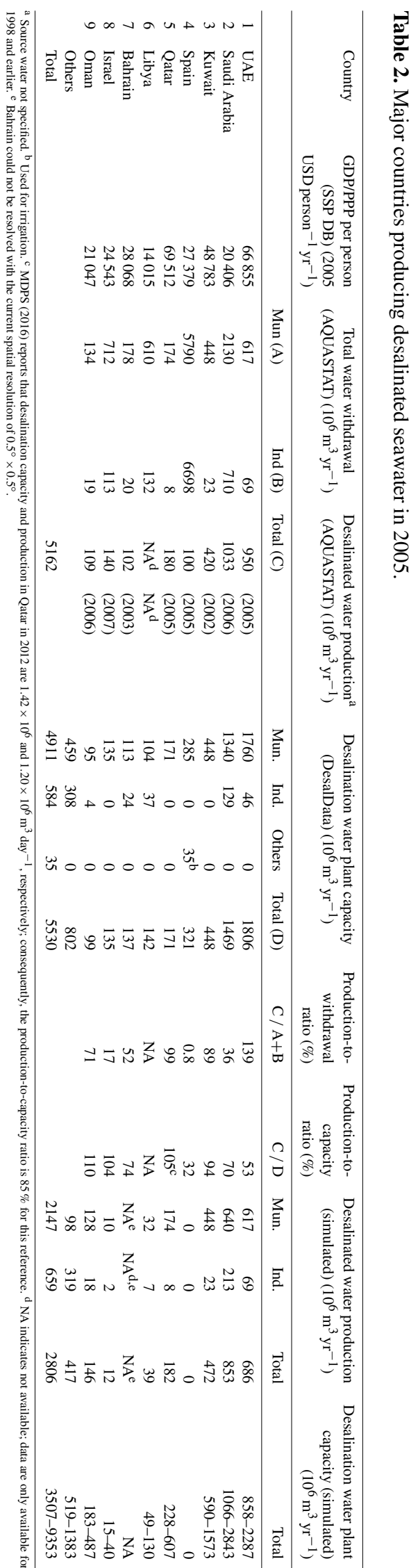

In this study, we developed SDM and its variant (hereafter SDM2). SDM2 has an identical model structure to SDM, but it consists of different objectives and sets of conditions and assumptions. SDM estimates AUSD cells where industrial and municipal water are mostly dependent on seawater desalination. As seen in Sect. 2.4, countries such as UAE and Qatar are typical cases. SDM2 estimates AUSD cells where industrial and municipal water are at least partly dependent on seawater desalination. Countries on the Mediterranean Sea are typical cases.

SDM extracts AUSD cells or the grid cells meeting the following three conditions:

Condition A Nations are included whose GDP exceeds 14000 USD PPP person ${ }^{-1} \mathrm{yr}^{-1}$.

Condition B AI is below $8 \%$.

Condition C Cells are located within three consecutive grid cells (approximately $165 \mathrm{~km}$ along the equator) of seashore.

In general, the desalination plants and the regions using their production are located in arid coastal zones in relatively high-income countries. The globally uniform thresholds were determined by the analyses given in Sect. 2.4. Table 2 shows that GDP exceeded 14000 USD PPP person $^{-1} \mathrm{yr}^{-1}$ in all of the major countries. Figure S2 shows that there is a breakpoint of desalination capacity at an $\mathrm{AI}$ of $8.2 \%$, but it was rounded to $8 \%$. Figure 3 shows that $90 \%$ of major plants are located $15 \mathrm{~km}$ from the seashore and $170 \mathrm{~km}$ from major cities, implying that seawater is transferred a distance of approximately three grid cells from the seashore. The thresholds are dependent on the climatological data used and spatial resolution of interest; hence, is expected to change if SDM is applied with different data at a different resolution. Several important factors relating to the design of the actual plants, such as the geographical suitability of seawater intake (Voutchkov, 2012), were excluded from this model because of the model's indefinite resolution and the lack of available global data.

SDM estimates desalinated water production under the following assumptions:

Assumption A Seawater desalination is used for municipal and industrial purposes, not for irrigation.

Assumption B All municipal and industrial water withdrawal in AUSD cells is supplied by seawater desalination.

Assumption C The production-to-capacity ratio, which shows the fraction of the seawater desalination production of a country relative to the total plant capacity is $30-80 \%$. 


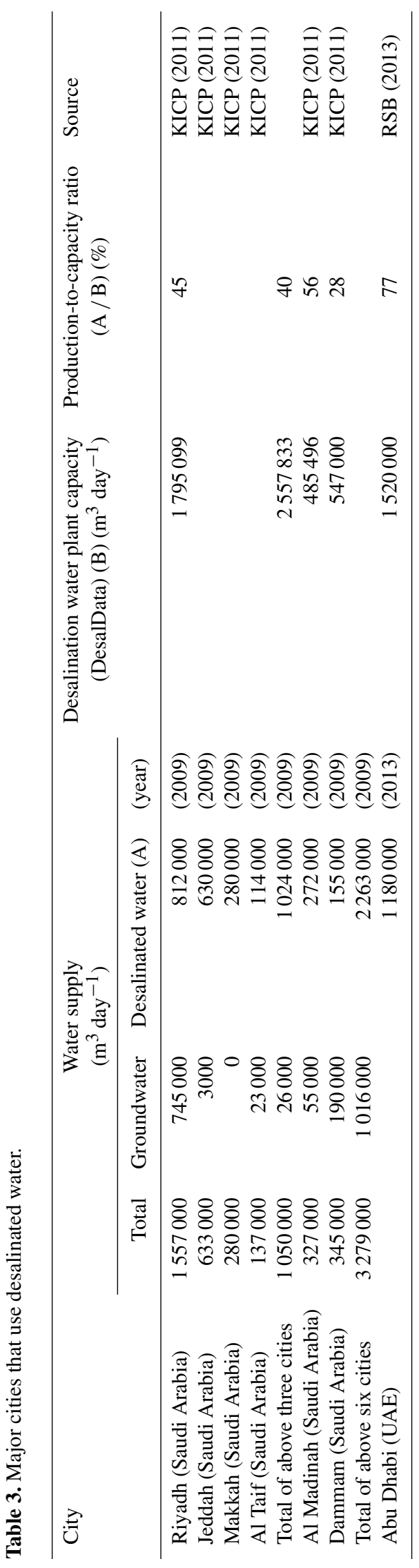

Combining these assumptions, AUSD cells, and gridbased requirement of water withdrawal, the volume of desalinated water production can be estimated, which is directly transferable to global hydrological models. The rationale of Assumption A is that desalinated water is not considered to be affordable for irrigation (e.g., Bremere et al., 2001). Note the production cost is approximated as $0.86-3.21 \mathrm{USD} \mathrm{m}^{-3}$ (Lamei et al., 2008). Also, this is supported by our findings from Table 2 . Assumption B is linked with Condition B: under such arid climatic conditions, surface water is hardly available unless major rivers are flowing (e.g., the Nile River in Egypt) and groundwater is not abundant over the long term because natural recharge must be virtually zero. This also implies a certain economic advantage of seawater desalination over alternative water sources, although we did not explicitly include the cost for each water source into our model. Assumption $\mathrm{C}$ is based on the findings of data analyses shown in Sect. 2.4. Note that the original range of the production-to-capacity ratio was $28-77 \%$, shown in Table 3, but it was rounded to $30-80 \%$.

SDM2 is a variant of SDM. SDM2 replaces Condition B of SDM with an AI below 50\% and adds a new Condition $\mathrm{D}$, which is that the withdrawal-to-water-resources ratio (WWR) is above $40 \%$. WWR is the ratio of annual total water withdrawal of all sectors to the mean annual renewable water resources typically substituted by annual runoff. Both AI and threshold WWR were devised by Raskin et al. (1997), and are widely accepted and used in quantitative macroscale water resource assessments (e.g., Vörösmarty et al., 2000; Oki et al., 2001). With these new conditions, SDM2 is able to identify the coastal regions with modest aridity and high water stress where actual major desalination plants are currently located.

Unlike SDM, it is difficult for SDM2 to maintain Assumption B. Outside hyper-arid climatic areas, in many cases, several water resource options are available, and seawater desalination only provides supplemental water. To estimate the desalination production, it is necessary to first identify how much of water withdrawal is assigned to seawater desalination. This could be partly achieved if SDM2 and GHMs such as H08 were fully coupled, but such modeling and simulations require considerable additional work and are beyond the scope of this paper. Therefore, SDM2 was only used to estimate AUSD cells, and not the volume of desalination.

\subsection{Simulations}

Four simulations were performed using SDM and SDM2. The first was a historical simulation for 2005, which was used for model validation. The results were used to validate 
the locations and production volumes of desalinated water. The remaining simulations were simulations of SSP1, SSP2, and SSP3 for three periods (2011-2040, 2041-2070, and 2071-2100), which were consistent with the projections of Hanasaki et al. (2013a, b). The results were used to assess future desalinated water use.

\section{Results and discussion}

\subsection{Historical simulation}

Historical simulations were performed to validate SDM and SDM2. First, we validated the geographical extent of the simulated AUSD cells. Validation was conducted in two steps. First, we checked whether AUSD cells existed in the major countries shown in Table 2. Next, we checked whether the AUSD cells included the grid cells with desalination plants shown in Fig. 1. The extent of AUSD cells is expected to be greater than the area of desalination plants, because desalinated water produced in a grid cell can be transferred to multiple cells through the pipeline system.

Figure 4a shows the AUSD cells derived from SDM. Recall that the objective of SDM was to identify the regions dependent, to a significant extent, on seawater desalination. The AUSD cells included the location of major plants in the Middle East (Fig. 1), spreading along the seashore in Kuwait, Saudi Arabia, UAE, Bahrain, Qatar, and Oman. Yemen was not included because it fell below the income threshold, which agreed well with Table 2 indicating that Yemen produces little desalinated water. Southern Oman was indicated as suitable for desalination, but this area had no desalination plants in 2005. This does not represent an overestimation of desalinated water production as the region is sparsely populated, and therefore water withdrawal is quite limited compared to the northeastern part of the country. Few AUSD cells are found in the Mediterranean except for a part of Libya, which is consistent with the findings in Sect. 2.4 that the fraction of desalination production to water withdrawal was relatively low in this region.

The simulated AUSD cells of SDM2 are shown in Figure 4b. AUSD cells were extensive not only in the Arabian peninsula but also in the Mediterranean region. These regions included the grid cells of the southeastern coast of Spain, western Mallorca, southern Sicily, and northwestern Libya, which agreed well with the actual distributions of major desalination plants (Fig. 1). In general, the AUSD cells of SDM2 were concentrated near the large cities, as compared to that of SDM. Although SDM2 performed well, particularly in the Mediterranean coastal regions, the AUSD cells of SDM2 differed from the actual situation in some cases. First, AUSD cells expand in large parts of the coastal regions of California in the USA (see Fig. S5a). Desalination plants exist in the region, but they produced marginal volume in 2005. Although the grid cells for California were categorized as a water-stressed area under the WWR index, in reality, water is effectively transferred long distances owing to California's long history of intensive water resource development. This implies that inter-grid water transfer should be taken into account when WWR is calculated. Another example is that, in reality, there are no plants at the southwestern edge of the Italian peninsula, but they do exist in the central northern coast of Algeria; however, the AUSD cells of SDM2 show the opposite. The geographical distributions of desalination plants reflect various local circumstances and it is difficult to estimate the AUSD grid by grid.

Because the stand-alone SDM2 model is unable to estimate the volume of production, the results from SDM are discussed hereafter. Table 2 includes the global and national volumes of desalinated water production for 2005 estimated by SDM. First, global total production and capacity of seawater desalination were estimated at $2.8 \times 10^{9}$ and $3.5-$ $9.4 \times 10^{9} \mathrm{~m}^{3} \mathrm{yr}^{-1}$, respectively. Note that the wide range in capacity reflects the production-to-capacity ratio included in Assumption C. The reported total global plant capacity in DesalData $\left(5.5 \times 10^{9} \mathrm{~m}^{3} \mathrm{yr}^{-1}\right)$ was within the range of the latter. Next, the simulation results for national production agreed fairly well with AQUASTAT (Fig. S2 shows a scatter plot of the data in Table 2). For Saudi Arabia, Kuwait, Qatar, and Oman, the simulated and reported desalinated water production agreed well with AQUASTAT. The simulation for UAE underestimated the data from AQUASTAT. This was largely attributable to an inconsistency within AQUASTAT, in which desalination production exceeds the total of municipal and industrial water withdrawal. The severe underestimation in Spain and Israel was mainly due to lack of AUSD estimation; there were no AUSD cells in Spain, and only one grid cell in Israel. Note that we could not perform the calculations for Bahrain because the area of land could not be resolved in our model.

At this stage, SDM has been validated mainly based on the spatial extent of areas and total volume of desalinated water production in 2005. Although a systematic validation of the temporal dynamics of desalinated water was hampered mainly by the lack of access to long-term data on socioeconomic conditions and water use, a simple validation was performed and is shown in Fig. 5. Conditions A-C and Assumptions A-C in SDM indicate that AUSD cells vary over time, due to changes in municipal and industrial water withdrawal, because the other factors are unchanged during the time frame of a few decades. Figure 5 shows the relationship between national desalination capacity and municipal and industrial water withdrawal in AUSD cells for different periods for 1980-2005 (the methods' summary is given in the Supplement). In general, the plots are located near the diagonal line. This supports Assumption B in SDM that the growth in municipal and industrial water in AUSD cells is sustained by seawater desalination. Exceptions are the cases of Spain and UAE. As we have mentioned several times above, AUSD cells in Spain are not well reproduced in this study. Although 
(a) 45

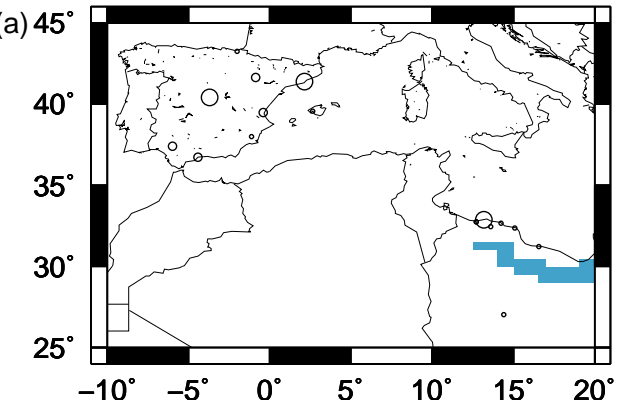

(b) $45^{\circ}$

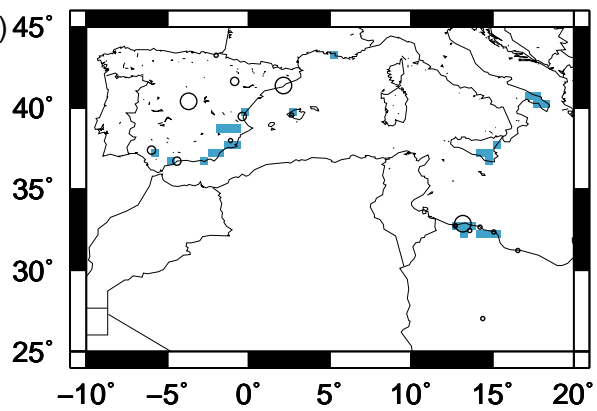

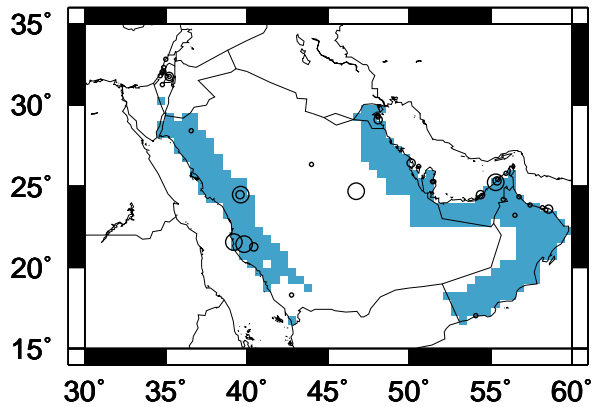

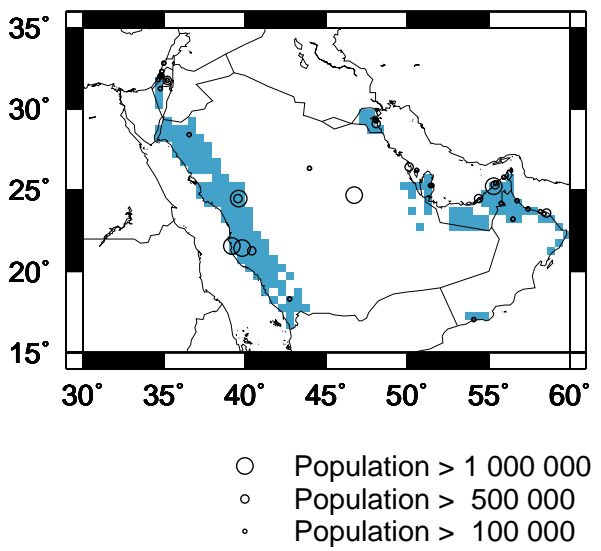

Figure 4. Simulated distribution of area utilizing seawater desalination (AUSD) in the Mediterranean and Middle East in 2005. (a) Results from SDM, (b) results from AUXSDM (see Sect. 3.2). Circles represent major cities (GeoNames).

desalination capacity substantially increased in UAE during the period, AQUASTAT reported little increase in municipal and industrial water withdrawal. Taking into account the marked economic growth in UAE during the period, we inferred that water withdrawal would have grown more than reported in AQUASTAT.

In summary, SDM was validated from three perspectives: geographical extent of AUSD cells (Fig. 4a), total desalinated water production in 2005 (Table 2 and Fig. S2), and temporal change in production (Fig. 5). The simulated regions that rely largely on seawater desalination were well reproduced, as compared to earlier studies referred to in the Introduction section. The regions are typically hyper-arid coastal regions where it is difficult to find alternative water sources. SDM also reproduced the reported volume of desalination production fairly well in the major countries. Because such countries dominate global water desalination, SDM also captured the total global volume reasonably well. Although SDM and SDM2 advance our resources for modeling global desalination, the results conveyed uncertainties, which can mainly be attributed to the limited availability of data and the simplicity of the model structure, similar to the future simulations described below. SDM2 was validated only for the geographical extent of AUSD cells. The performance was promising because it reproduced reasonably well the present distribution of major plants.
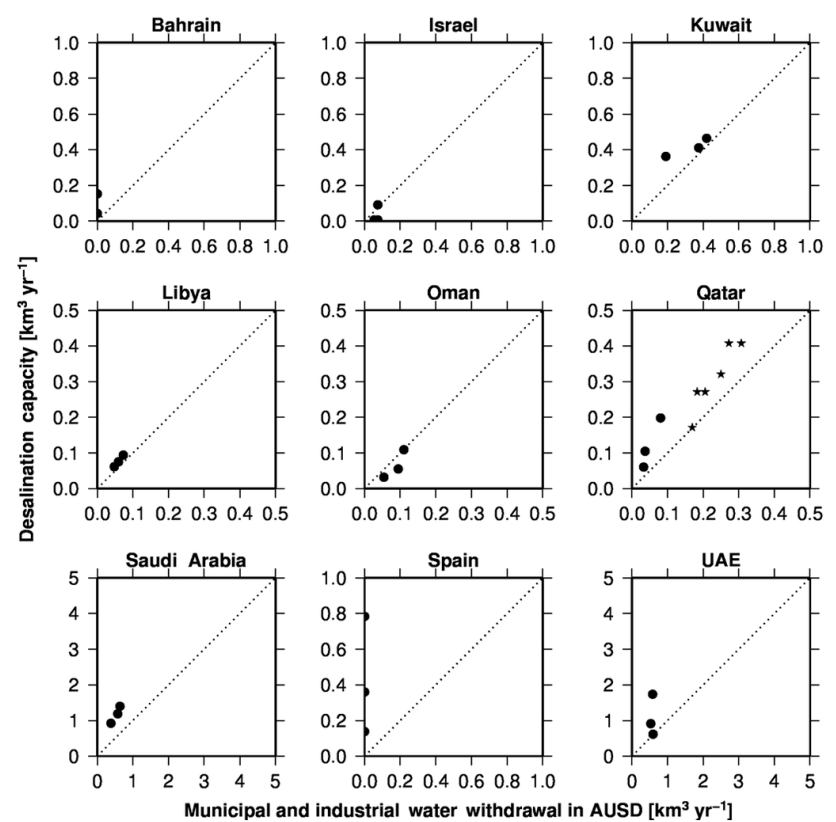

Figure 5. Comparison between national desalination capacity and municipal and industrial water withdrawal in AUSD cells. Each plot indicates one specific year. The shape of symbols indicate the data source of municipal and industrial water withdrawal in AUSD cells: circles for AQUASTAT and stars for MDPS (2016). 
(a) Present

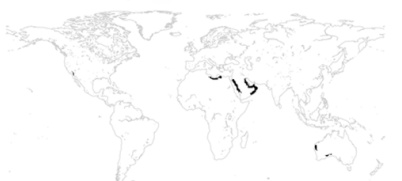

(c) SSP2

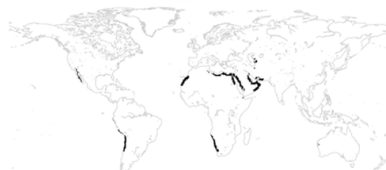

(e) Plant distribution in 2005

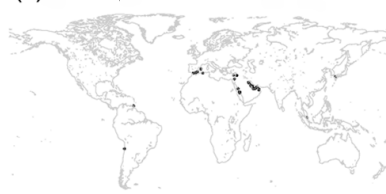

(b) SSP1

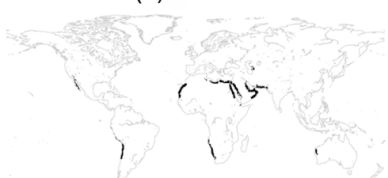

(d) SSP3

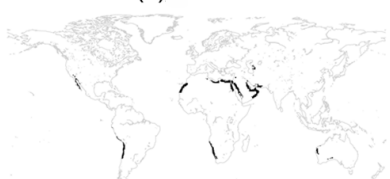

(f) Plant distribution in 2014

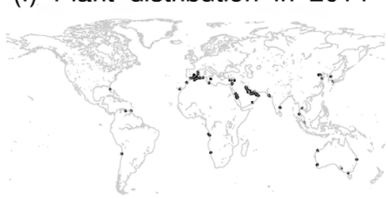

Figure 6. Global distributions of area utilizing seawater desalination (AUSD) in (a) 2005, (b) SSP1 in 2055, (c) SSP2 in 2055, and (d) SSP3 in 2055. Locations of seawater desalination plants (larger than $50000 \mathrm{~m}^{3}$ day $^{-1}$ in capacity) in (e) 2005 and (f) 2014.

\subsection{Future simulation}

For future simulation, we mainly report the results of SDM because it produced outputs of both AUSD cells and the volume of desalinated water production. Figure 6 shows the estimated spread of AUSD cells at present and in 2055 under SSP1, SSP2, and SSP3 scenarios together with the actual distribution of extra-large desalination plants (capacity $\geq 50000 \mathrm{~m}^{3} \mathrm{~d}^{-1}$ ) that meet the criteria shown in Table $\mathrm{S} 1$ in 2005 and 2014. For all cases in 2055, AUSD cells have expanded considerably compared to the present. The change in AUSD cells can be largely explained by growth in income, with the change in AI due to climate change playing a marginal role. In the case of SSP1, AUSD cells showed marked expansion of grid cells including Baja California in Mexico, northern Chile, the coastline of northern Africa, and southwest Africa. Note that the coastlines on the Caspian Sea in central Asia became AUSD cells, as the inland lake is categorized as a sea. The expansions of SSP2 and SSP3 were somewhat limited compared to SSP1 because income levels in these scenarios were lower than in SSP1 (see Fig. S3). For example, the AUSD cells of SSP1 exclusively include Mauritania, Sudan, and Pakistan. The AUSD cells of SSP2 show no AUSD cells in Australia, which is attributed to wet climate under this scenario. As all SSP scenarios project considerable income growth with national income exceeding 14000 USD PPP person $^{-1} \mathrm{yr}^{-1}$ for most countries in the world (Table 1 and Fig. S3), AUSD cells are expected to expand into most of the arid areas in the world by 2055 (compare Figs. 2 and 6).
It is difficult to assess the validity of future projections, but comparing AUSD projections with the present distribution of desalination plants (shown in Fig. 6e, f) can provide some insights. Interestingly, although production in 2005 was not significant, several desalination plants were actually operational in southern Africa and northern Chile, which is consistent with our AUSD expansion. In contrast, although at least one extra-large plant was located in Algeria, Angola, northern China, southeastern India, Japan, Korea, Singapore, Thailand, Florida in the USA, and Venezuela in 2014, AUSD cells did not cover these regions in any scenarios. This was primarily attributable to Condition B in SDM, which excluded non-hyper-arid regions. (As mentioned above, AUSD projections using SDM2 are shown in Fig. S5.) AUSD cells of SDM2 expanded into Algeria, northern China, and southeastern India, which was consistent with the distribution in 2014. AUSD cells did not expand into other east and southeast Asian countries because their AI was too high.

Using SDM, the projected levels of desalinated water production in 2025 and 2055 are 1.4-2.1 and 6.7-17.3 times greater than present, respectively (Table 4$)$. The earlier estimates show a considerable range, but our results are within the range of spread for the reported period of 2015-2025. Only one earlier report was found with projections for the year 2050. Fichtner GmbH (2011) reported that total desalination production would be as high as $96800 \times 10^{6} \mathrm{~m}^{3} \mathrm{yr}^{-1}$, which is more than double our estimate under SSP3. Their projection is based on the assumption that concentrating solar power (CSP) desalination, which is an emerging technology for producing desalinated water without fuel consumption, would extend widely throughout MENA. Although the technical problems are substantial for large-scale installation of CSP desalination plants, the development of new technology may lead to further increases in desalination production. Among the three SSPs, the volume of desalination is greatest in SSP3. This is primarily due to the higher water demand in SSP3, which is accompanied by higher population and lower efficiency (Hanasaki et al., 2013a). The considerable growth in desalination in SSP3 may be perceived as contradictory to its narrative scenario: SSP3 depicts a world of low income and inefficiency; i.e., one in which it will be difficult to adapt to and mitigate climate change. It is also true, however, that the country-based GDPPC grows steadily and considerably in all SSP scenarios. The world in SSP3 is poorer and more fragmented than in other SSPs, but that does not mean poorer than the present day.

Further regional breakdown is illustrated in Table 5. We followed the regional classification of the SSP scenarios, which subdivides the world into 11 regions (see Table S4 for the list of countries). In 2005, $85 \%$ of the production was concentrated in MENA (including all major countries except Spain). The second largest region of production was North America, which requires caution in its interpretation. A total of $409 \times 10^{6} \mathrm{~m}^{3} \mathrm{yr}^{-1}$ of seawater desalination in this region was attributed to the AUSD cells of seven grid cells 
Table 4. Projected future production of desalinated water.

\begin{tabular}{|c|c|c|c|c|c|c|c|}
\hline & Period & Domain & $\begin{array}{r}\text { Desalination production } \\
\text { from seawater } \\
\left(\times 10^{6} \mathrm{~m}^{3} \mathrm{yr}^{-1}\right)\end{array}$ & $\begin{array}{r}\text { Installed capacity } \\
\text { for seawater } \\
\left(\times 10^{6} \mathrm{~m}^{3} \mathrm{yr}^{-1}\right)\end{array}$ & $\begin{array}{r}\text { Installed capacity } \\
\text { for all sources } \\
\left(\times 10^{6} \mathrm{~m}^{3} \mathrm{yr}^{-1}\right)\end{array}$ & $\begin{array}{l}\text { Production cost } \\
\qquad\left(\times 10^{6} \text { USD }\right)\end{array}$ & $\begin{array}{r}\text { Production cost } \\
\text { to GDP } \\
(\%)\end{array}$ \\
\hline \multicolumn{8}{|l|}{ Historical } \\
\hline This study & 2005 & Globe & 2806 & $3507-9353^{\mathrm{a}}$ & - & $1122-10606$ & $0.002-0.019$ \\
\hline AQUASTAT & 2003-2007 & Globe & $5162^{b}$ & - & - & - & - \\
\hline DesalData & 2005 & Globe & - & 6900 & 12100 & - & - \\
\hline Bremere et al. (2001) & 2000 & 10 countries $^{\mathrm{c}}$ & - & $1680^{\mathrm{d}}$ & 2660 & - & - \\
\hline \multicolumn{8}{|l|}{ Future (near term) } \\
\hline This study (SSP1) & 2025 & Globe & 4050 & $5063-13500$ & - & $1620-15310$ & $0.001-0.012$ \\
\hline This study (SSP2) & 2025 & Globe & 5344 & $6680-17814$ & - & $2138-20201$ & $0.002-0.017$ \\
\hline This study (SSP3) & 2025 & Globe & 6030 & $7537-20100$ & - & $2412-22793$ & $0.002-0.020$ \\
\hline Bremere et al. (2001) & 2025 & 10 countries $^{\mathrm{c}}$ & - & $5080^{\mathrm{d}}$ & 8070 & - & 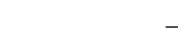 \\
\hline \multicolumn{8}{|l|}{ Future (long term) } \\
\hline This study (SSP1) & 2055 & Globe & 18702 & $23378-62342$ & - & $7481-70695$ & $0.002-0.022$ \\
\hline This study (SSP2) & 2055 & Globe & 40306 & $50383-134354$ & - & $16123-152358$ & $0.006-0.060$ \\
\hline This study (SSP3) & 2055 & Globe & 48638 & $60797-162126$ & - & $19455-183851$ & $0.011-0.100$ \\
\hline Fichtner GmbH (2011) & 2050 & MENA $^{\mathrm{e}}$ & 96797 & - & - & - & - \\
\hline
\end{tabular}

in southern California, USA. In particular, two grid cells including the suburbs of Palm Springs and El Centro were responsible for most of the production. In reality, there was no seawater desalination in these regions as of 2005, and SDM failed to reproduce the real situation for these cases. This does not necessarily mean that SDM is completely unreliable; in fact, several very large desalination plants are under planning in surrounding areas (e.g., the Carlsbad desalination plant in San Diego started operating in 2015). MENA was projected to continue producing the largest volume of seawater desalination in 2025. Several new regions appear in the table, notably Latin America and the Caribbean. The emergence of these countries is mainly due to the GDP per person of Mexico, Chile, and Peru exceeding the threshold of 14000 USD PPP person $^{-1} \mathrm{yr}^{-1}$. In 2055, in SSP1, GDP per person will exceed the threshold in two densely populated countries, Egypt and Pakistan, which caused a marked increase in seawater desalination in MENA and southern Asia (ibid). Again, interpretation of these results requires caution. The AUSD cells in Egypt and Pakistan included grid cells through which the Nile and Indus rivers flow, respectively. Although these grid cells are located in extremely dry conditions, it is likely that water is supplied from these rivers to the cells. Assumption B would be not valid for these grid cells; hence, the AUSD cells may be overestimated. To improve the reliability of the projections, the availability of alternative water resources should be evaluated at each grid cell. Such simulations should be implemented when the SDM is fully integrated into global hydrological models with detailed water use submodels, such as the H08 model (Hanasaki et al., 2008a, b).

The economic cost of seawater desalination was estimated for each case (Table 4 for worldwide, Tables S5 and S6 for regions). Adopting the method of Lamei et al. (2008), we estimated the unit production costs at $0.40-3.78$ USD m $^{-3}$ based on the data available for 186 plants globally (see the Supplement for details). As shown in Table 4, the volume of seawater desalination was estimated at $2.8 \times 10^{9} \mathrm{~m}^{3} \mathrm{yr}^{-1}$, with a cost of USD 1.1-10.6 × $10^{6}$, equivalent to $0.002-0.019 \%$ of total global GDP. This number is much higher in MENA, with values of $0.032-0.306 \%$. Among the scenarios, SSP3 in 2055 showed the highest numbers at $0.011-0.100 \%$ globally and $0.121-1.147 \%$ for MENA. This was mainly attributable to large water use and low GDP growth in SSP3.

The future projection is sensitive to Condition A (threshold of 14000 USD PPP person $^{-1} \mathrm{yr}^{-1}$ ), Condition B (aridity index of 0.08), and Condition C (three grid cells of seashore). Here, we conducted a sensitivity test on these thresholds. We examined thresholds of 0,7000 , and 24000 USD PPP person $^{-1} \mathrm{yr}^{-1}$ for Condition A. A threshold of 7000 USD PPP person $^{-1} \mathrm{yr}^{-1}$ implies further reduction in cost due to technological change, while 0 implies that seawater desalination economically outperforms traditional water resource development in arid regions. The threshold

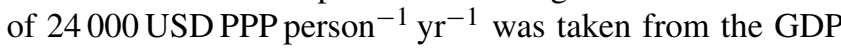
per capita of Israel, one of the non-oil-producing nations in Table 2. Present Condition A was taken from the GDP per capita of Libya, which is an oil-producing nation. We con- 
Table 5. Production of desalinated water by region $\left(10^{6} \mathrm{~m}^{3} \mathrm{yr}^{-1}\right)$. See Table S4 for classification of countries.

\begin{tabular}{lrrrrrrr}
\hline Region & 2005 & 2025 & & & 2055 & & \\
& & SSP1 & SSP2 & SSP3 & SSP1 & SSP2 & SSP3 \\
\hline Sub-Saharan Africa & 0 & 4 & 7 & 7 & 189 & 168 & 61 \\
Centrally planned Asia and China & 0 & 0 & 0 & 0 & 0 & 0 & 0 \\
Central and eastern Europe & 0 & 0 & 0 & 0 & 0 & 0 & 0 \\
Former Soviet Union & 0 & 18 & 22 & 32 & 13 & 42 & 54 \\
Latin America and the Caribbean & 0 & 1157 & 1441 & 1715 & 95 & 1846 & 2896 \\
Middle East and north Africa & 2389 & 2454 & 3353 & 3689 & 15245 & 37610 & 44890 \\
North America & 409 & 406 & 517 & 579 & 311 & 638 & 725 \\
Pacific OECD & 8 & 10 & 4 & 8 & 5 & 3 & 12 \\
Other Pacific Asia & 0 & 0 & 0 & 0 & 0 & 0 & 0 \\
South Asia & 0 & 0 & 0 & 0 & 1964 & 0 & 0 \\
Western Europe & 0 & 0 & 0 & 0 & 0 & 0 & 0 \\
World & 2806 & 4050 & 5344 & 6030 & 18702 & 40306 & 48638 \\
\hline
\end{tabular}

sidered that the threshold for oil-producing nations may be lower than for other countries due to massive consumption of fossil fuels for desalination. Similarly, we tested thresholds of 0.15 and 0.2 for Condition B, which expanded the potential area for AUSD cells (see Fig. 2), and two and four grid cells of seashore for Condition C.

The results of the sensitivity tests are shown in Fig. 7. First, a higher threshold of GDP per capita decreases the total desalination production due to reduction in AUSD cells. For the base year (2005), there is a gap between 0 and 7000 USD PPP person ${ }^{-1} \mathrm{yr}^{-1}$. In contrast, there is no change in SSP1 between 0 and 14000 USD PPP person ${ }^{-1} \mathrm{yr}^{-1}$, as GDP per capita exceeds 14000 for most countries (see Fig. S4). The large drop between USD 14000 and 24000 for SSP3 indicates that in this scenario a large number of countries cannot exceed a GDP per capita of 24000 by 2055 (i.e., the growth in GDP per capita in SSP3 is considerably slower than in the other scenarios). The discrepancies among SSPs are attributable to differences in water use. Hanasaki et al. (2013a) projected the lowest water use for SSP1 due to rapid decreases in municipal and industrial water use intensity, with the opposite being true for SSP3. The sensitivity test of AI showed a linear response (only the results of SSP1 are shown in Fig. 7) due to gradual changes in AI (see also Fig. 2) and grid cells of seashore. Desalination production expands by increases in AI and the grid cells of seashore. The expansion was not proportional to the change in AI and the number of grid cells reflecting the complex geographical distribution of $\mathrm{AI}$ and shape of the coastline.

\subsection{Implications in the context of global water resource assessment}

In 2005, the global total for industrial and domestic water withdrawal was reported to be $1170 \mathrm{~km}^{3} \mathrm{yr}^{-1}$ (AQUASTAT). In this study, desalination production was estimated at $2.8 \mathrm{~km}^{3} \mathrm{yr}^{-1}$ for these two purposes, accounting for $0.24 \%$

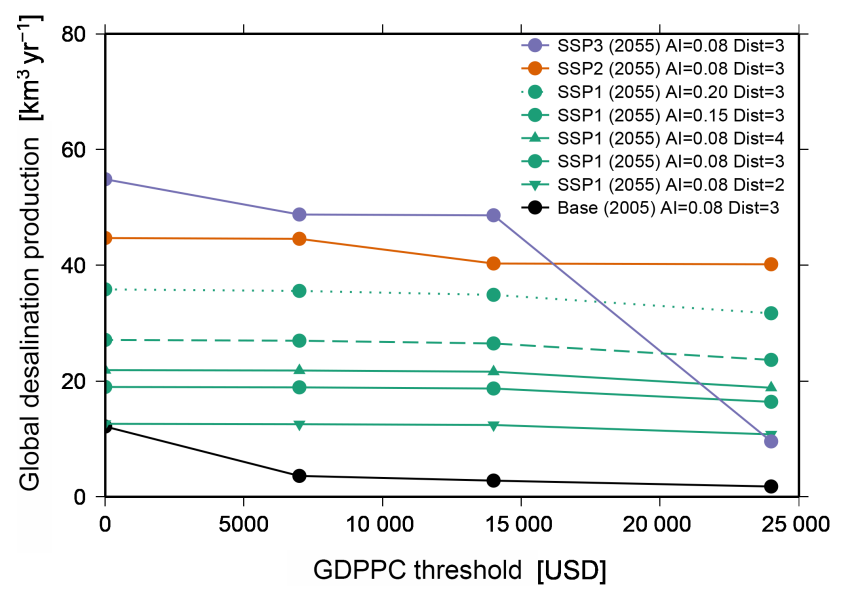

Figure 7. Sensitivity of GDP per capita (GDPPC; Condition A) and the aridity index (AI; Condition B) with respect to global total production of seawater desalination. Black, blue, green, and red lines for base year (2005), SSP1, SSP2, and SSP3 in 2055, respectively. Solid, broken, and dotted lines for $\mathrm{AI}=0.08, \mathrm{AI}=0.15$, and $\mathrm{AI}=0.2$, respectively. The sensitivity of AI is only shown for SSP1 in 2055 .

of the total. As shown in Table 1, water withdrawal will change considerably in the future. In the case of SSP1, which depicts a sustainable world, the projected water withdrawal is $1142 \mathrm{~km}^{3} \mathrm{yr}^{-1}$ in 2055 , showing almost no change from the present. However, in SSP3, which depicts a fragmented world, withdrawal will be more than double and reach $2831 \mathrm{~km}^{3} \mathrm{yr}^{-1}$. The estimated seawater desalination production levels are 18.7 and $48.6 \mathrm{~km}^{3} \mathrm{yr}^{-1}$ for these scenarios, accounting for 1.6 and $1.7 \%$ of the global requirement, respectively. Although this portion appears small, desalinated water plays a critical role in AUSD cells. The population in the AUSD cells is estimated at 12.8 million in 2005, but by 2055 , it is expected to increase to 138 million in SSP1, and 170 million in SSP3. The substantial increase in num- 
ber was mainly attributable to AUSD cells extending into densely populated northern Africa and part of south Asia. As the AUSD cells are located in extremely dry regions, vulnerable to water scarcity, it is crucial to secure municipal and industrial water for water security and human well-being in AUSD regions. Moreover, the estimated geographical extent of present and future AUSD cells largely overlap with regions where water resources are projected to decrease due to climate change, typically in the Mediterranean (Jiménez Cisneros et al., 2014).

\subsection{Key uncertainties and limitations}

The SDM model estimates AUSD cells and the volume of desalinated seawater based on three conditions and three assumptions. The results demonstrate that these conditions and assumptions allow us to successfully simulate seawater desalination in accordance with the purpose of this study. Here, each condition and assumption is revisited and key uncertainties are discussed.

Conditions $\mathrm{A}$ and $\mathrm{B}$, which set thresholds on national average income and aridity, explain the present distribution of major desalination plants and regions that are dependent on seawater desalination. It should be noted that countries meeting these conditions include major oil-producing countries. Seawater desalination has high energy consumption costs, even with the application of the latest technology. Hence, the price of energy is an important factor in the installation of desalination plants. Although we confirmed that non-oilproducing countries such as Spain and Israel had considerable desalination capacity, attention should be paid to the projected newly emerging AUSD cells in non-oil-producing countries under the SSP scenarios, such as Chile, Namibia, etc. The income threshold may differ for these nations compared to major oil-producing countries because of differences in energy prices. These regional biases cannot be completely eliminated from our model simulations and validation because the majority of desalination plants have, so far, been constructed in the Middle East. It should also be noted that we fixed the thresholds for income and aridity according to Conditions A and B throughout the study period. This corresponds to the assumption that technology and costs of production are essentially fixed at present. Advances in technology would likely further lower the production costs, which would alter the threshold for plant installation (e.g., Ghaffour et al., 2013; Ziolkowska et al., 2015).

Condition $\mathrm{C}$, which sets the maximum distance from the seashore for AUSD cells, plays a crucial role in the simulated volume of desalinated water. Desalinated water can be used at large distances from the seashore if transportation costs are affordable. Assumption B, or $100 \%$ dependence on desalination in AUSD cells, is probably the largest uncertainty in the SDM. Although surface water is unreliable under super-arid conditions in AUSD cells, the dependence is influenced by the availability of other water sources, typically rivers, groundwater, and sometimes long-distance water transfer (Lamei et al., 2008). Recycled water is another emerging source of freshwater in water-scarce regions. For example, Singapore has been strongly promoting recycled water usage, which is economically more efficient than seawater desalination due to Singapore's stringent waste water quality control and appropriate infrastructure (Tortajada, 2006). In contrast, major desalination plants are occasionally implemented in relatively wet regions, e.g., on islands that are characterized by relatively small catchment areas, limited storage capacities, and large temporal variations in water demand. Such regional details are beyond the capability of present global hydrological models, but may substantially affect the results in some places.

In this study, we used the future water use projection of Hanasaki et al. (2013a) based on empirical relationships between water use and population and electricity production excluding regional details, and therefore projections for individual nations include substantial uncertainty. The spatial distribution of water use is another source of uncertainty. Historical and future water use are obtained first at the national scale, and then converted into grid cells under various assumptions. This study adopted the assumption that the spatial distribution of municipal and industrial water use is proportional to that of population. We note that supply and demand are interconnected: seawater desalination relieves the availability of water constrained by hydrology. Increases in water availability may enhance water consumption. This may alter the future situation substantially from the historical past on which the water demand projections of Hanasaki et al. (2013a) were based. Water use projections substantially differ among models and a systematic model intercomparison is under way (Wada et al., 2016).

Finally, we summarize the limitations due to the preconditions of the SDM model. First, SDM was designed to be incorporated into GHMs, typically simulated at a spatial resolution of $0.5^{\circ} \times 0.5^{\circ}$ (approximately $55 \times 55 \mathrm{~km}$ at the equator). It is impossible to resolve individual plants with this spatial scale; hence, this is outside the scope of this model. Second, although the cost of desalination and its difference in cost to alternative sources play a crucial role in desalination projects in reality, this price mechanism is not included in the present formulation of SDM. Third, partly as a consequence of the previous factor, SDM is unable to analyze the effects of technological advances and subsequent cost reductions on the introduction of new desalination plants to regions with wetter climates and lower incomes. The results of the sensitivity test of changing the threshold of Condition A (minimum GDP per capita; Fig. 7) and Condition B (maximum AI) provided us with several useful insights, but further investigations are necessary to assess the combined effect. Fourth, the availability of alternative water resources cannot be estimated by the stand-alone SDM model. Such analyses would be feasible if we combined SDM2 with a global hydrological model that explicitly simulates 
renewable/fossil groundwater. Fifth, the thresholds in SDM were fixed throughout the simulation period. The abovementioned factors, namely the relative cost of desalination relative to alternative water sources, technological advances in desalination, and availability of alternative water sources, might change the thresholds in the future. Sixth, the conditions and assumptions used for future simulations were independent of the narrative scenarios of the SSPs. Reflecting the conditions and assumptions in the narrative scenarios would enhance the consistency between our study and the SSPs (e.g., SSP1 depicts a world of sustainability; hence, conventional energy-intensive desalination plants would not be favored). Seventh, in general, the performance of SDM is highly dependent on the availability of data. In this study, we mainly used datasets with global coverage (DesalData and AQUASTAT), and reports published by academic and governmental institutions written in English. Reports published by the private sector and written in local languages were not collected due to limitations in capability and resources. International collaboration would be needed to enable systematic collection of further data.

\section{Conclusions}

We have developed two models to estimate the location and volume of desalinated water production. First, we identified climatic and socioeconomic conditions that are common to areas where seawater desalination is undertaken. Three typical conditions were found, i.e., relatively high income, aridity, and proximity to the seashore. We obtained common global parameters for each, and demonstrated that the present AUSD cells can be fairly well reproduced by the proposed model. Then, we assumed that municipal and industrial water in AUSD cells are fully supplied by seawater desalination, and estimated the production and plant capacity of seawater desalination. We achieved fairly strong agreement with independent data. Second, using the SDM and SSP socioeconomic scenarios, the future production of desalination water was projected globally. The results indicated that AUSD cells are expected to expand considerably in the 21 st century. Income growth plays a primary role in the expansion of desalination plants.

Desalination is a practical engineering measure for meeting the growing water demand in arid regions and for adapting to climate change (Jiménez Cisneros et al., 2014). This study proposes one of the first models to express desalination in global water resource models supported by the available literature and technologies. Although further improvements are needed, the model provides a good starting point for dynamically incorporating information regarding desalination into global water resource assessment.

\section{Data availability}

Data used in this paper is available upon request to the corresponding author except for the data regarding the desalination plants database because redistribution is prohibited by the data provider. Please contact Desal Data (https: //www.desaldata.com/) for the database.

\section{The Supplement related to this article is available online at doi:10.5194/hess-20-4143-2016-supplement.}

Acknowledgements. This work was mainly supported by CREST, Japan Science and Technology Agency. N. Hanasaki acknowledges the support of JSPS KAKENHI grant number 25820230 and the Environment Research and Technology Development Fund (S-14) of the Ministry of the Environment, Japan. S. Yoshikawa, K. Kakinuma, and S. Kanae acknowledge the support of JSPS KAKENHI Grant number 15H04047 and 16H06291. The authors are grateful to three anonymous reviewers, Yoshie Maeda, and Yaling Liu for helpful suggestions. The present work was partially developed within the framework of the Water Futures and Solutions initiative at IIASA and the Panta Rhei Research Initiative of the International Association of Hydrological Sciences (IAHS) by the Water Scarcity Assessment: Methodology and Application working group. Map colors are based on www.colorbrewer.org, by Cynthia A. Brewer of Pennsylvania State University.

Edited by: M. Sivapalan

Reviewed by: three anonymous referees

\section{References}

Bremere, I., Kennedy, M., Stikker, A., and Schippers, J.: How water scarcity will effect the growth in the desalination market in the coming 25 years, Desalination, 138, 7-15, doi:10.1016/S00119164(01)00239-9, 2001.

Döll, P., Müller Schmied, H., Schuh, C., Portmann, F. T., and Eicker, A.: Global-scale assessment of groundwater depletion and related groundwater abstractions: Combining hydrological modeling with information from well observations and GRACE satellites, Water Resour. Res., 50, 5698-5720, doi:10.1002/2014wr015595, 2014.

Eastman, J. R.: IDRISI Taiga guide to GIS and image processing, Clark University, Massachusetts, USA, 342, 2009.

Environment Agency Abu Dhabi (EAAD): Advancing sustainable groundwater management in Abu Dhabi, Abu Dhabi, 19, 2012.

Fichtner GmbH: MENA Regional Water Outlook Part II: Desalination Using Renewable Energy, Fichtner, Stuttgart, Germany, 272, 2011.

Ghaffour, N., Missimer, T. M., and Amy, G. L.: Technical review and evaluation of the economics of water desalination: Current and future challenges for better water supply sustainability, Desalination, 309, 197-207, doi:10.1016/j.desal.2012.10.015, 2013. 
Hackley, R.: "Desalination plants supply $98.8 \%$ of Dubai's water," forum is told, in: Bloomberg Business, 23 September 2013.

Hanasaki, N., Kanae, S., Oki, T., Masuda, K., Motoya, K., Shirakawa, N., Shen, Y., and Tanaka, K.: An integrated model for the assessment of global water resources - Part 1: Model description and input meteorological forcing, Hydrol. Earth Syst. Sci., 12, 1007-1025, doi:10.5194/hess-12-1007-2008, 2008a.

Hanasaki, N., Kanae, S., Oki, T., Masuda, K., Motoya, K., Shirakawa, N., Shen, Y., and Tanaka, K.: An integrated model for the assessment of global water resources - Part 2: Applications and assessments, Hydrol. Earth Syst. Sci., 12, 1027-1037, doi:10.5194/hess-12-1027-2008, 2008b.

Hanasaki, N., Fujimori, S., Yamamoto, T., Yoshikawa, S., Masaki, Y., Hijioka, Y., Kainuma, M., Kanamori, Y., Masui, T., Takahashi, K., and Kanae, S.: A global water scarcity assessment under Shared Socio-economic Pathways - Part 2: Water availability and scarcity, Hydrol. Earth Syst. Sci., 17, 2393-2413, doi:10.5194/hess-17-2393-2013, 2013a.

Hanasaki, N., Fujimori, S., Yamamoto, T., Yoshikawa, S., Masaki, Y., Hijioka, Y., Kainuma, M., Kanamori, Y., Masui, T., Takahashi, K., and Kanae, S.: A global water scarcity assessment under Shared Socio-economic Pathways - Part 2: Water availability and scarcity, Hydrol. Earth Syst. Sci., 17, 2393-2413, doi:10.5194/hess-17-2393-2013, 2013b.

Jiménez Cisneros, B. E., Oki, T., Arnell, N. W., Benito, G., Cogley, J. G., Döll, P., Jiang, T., and Mwakalila, S. S.: Freshwater Resources, in: Climate Change 2014: Impacts, adaptation, and vulnerability Part A: Global and sectoral aspects. Contribution of Working Group II to the Fifth Assessment Report of the Intergovernmental Panel on Climate Change, edited by: Field, C. B., Barros, V. R., Dokken, D. J., Mach, K. J., Mastrandrea, M. D., Bilir, T. E., Chatterjee, M., Ebi, K. L., Estrada, Y. O., Genova, R. C., Girma, B., Kissel, E. S., Levy, A. N., MacCracken, S., Mastrandrea, P. R., and White, L. L., Cambridge University Press, Cambridge, United Kingdom and New York, NY, USA, 229-269, 2014.

Kim, S. H., Hejazi, M., Liu, L., Calvin, K., Clarke, L., Edmonds, J., Kyle, P., Patel, P., Wise, M., and Davies, E.: Balancing global water availability and use at basin scale in an integrated assessment model, Climatic Change, 136, 217-231, doi:10.1007/s10584016-1604-6, 2016.

King Abdullah University of Science and Technology Industry Collaboration Program (KICP): Promoting wastewater reclamation and reuse in the Kingdom of Saudi Arabia: Technology trends, innovation needs, and business opportunities, King Abdullah University of Science and Technology, Thuwal, Saudi Arabia, 2011

Lamei, A., van der Zaag, P., and von Münch, E.: Basic cost equations to estimate unit production costs for RO desalination and long-distance piping to supply water to tourismdominated arid coastal regions of Egypt, Desalination, 225, 112, doi:10.1016/j.desal.2007.08.003, 2008.

Lattemann, S., Kennedy, M. D., Schippers, J. C., and Amy, G.: Chapter 2 Global desalination situation, in: Sustainability science and engineering, edited by: Isabel, C. E. and Andrea, I. S., Elsevier, 7-39, 2010.
Ministry of Development Planning and Statistics (MDPS): Water Statistics: In the state of Qatar 2013, Ministry of Development Planning and Statistics, Qatar, 48, 2016.

Oki, T., Agata, Y., Kanae, S., Saruhashi, T., Yang, D. W., and Musiake, K.: Global assessment of current water resources using total runoff integrating pathways, Hydrolog. Sci. J., 46, 983-995, 2001.

Oki, T., Agata, Y., Kanae, S., Saruhashi, T., and Musiake, K.: Global water resource assessment under climatic change in 2050 using TRIP, IAHS Publication, 280, 124-133, 2003.

O’Neill, B., Kriegler, E., Riahi, K., Ebi, K., Hallegatte, S., Carter, T., Mathur, R., and van Vuuren, D.: A new scenario framework for climate change research: the concept of shared socioeconomic pathways, Climatic Change, 122, 387-400, doi:10.1007/s10584013-0905-2, 2014.

Ouda, O. K. M.: Water demand versus supply in Saudi Arabia: current and future challenges, Int. J. Water Resour. D., 30, 335-344, doi:10.1080/07900627.2013.837363, 2014.

Raskin, P., Gleick, P., Kirshen, P., Pontius, G., and Strzepek, K.: Comprehensive assessment of the freshwater resources of the world, Stockholm Environment Institute, Stockholm, Sweden, 1997.

Regulation and Supervision Bureau (RSB): Annual report 2013, Regulation and Supervision Bureau, Emirate of Abu Dhabi, 39, 2013.

Tortajada, C.: Water management in Singapore, Int. J. Water Resour. D., 22, 227-240, doi:10.1080/07900620600691944, 2006.

Vörösmarty, C. J., Green, P., Salisbury, J., and Lammers, R. B.: Global water resources: Vulnerability from climate change and population growth, Science, 289, 284-288, 2000.

Voutchkov, N.: Desalination engineering: Planning and design, McGraw-Hill Professional Publishing, 2012.

Wada, Y. and Bierkens, M. F. P.: Sustainability of global water use: past reconstruction and future projections, Environ. Res. Lett., 9, 104003, doi:10.1088/1748-9326/9/10/104003, 2014.

Wada, Y., van Beek, L. P. H., and Bierkens, M. F. P.: Modelling global water stress of the recent past: on the relative importance of trends in water demand and climate variability, Hydrol. Earth Syst. Sci., 15, 3785-3808, doi:10.5194/hess-15-37852011, 2011.

Wada, Y., Flörke, M., Hanasaki, N., Eisner, S., Fischer, G., Tramberend, S., Satoh, Y., van Vliet, M. T. H., Yillia, P., Ringler, C., Burek, P., and Wiberg, D.: Modeling global water use for the 21st century: the Water Futures and Solutions (WFaS) initiative and its approaches, Geosci. Model Dev., 9, 175-222, doi:10.5194/gmd-9-175-2016, 2016.

Weedon, G. P., Gomes, S., Viterbo, P., Shuttleworth, W. J., Blyth, E., Österle, H., Adam, J. C., Bellouin, N., Boucher, O., and Best, M.: Creation of the WATCH forcing data and its use to assess global and regional reference crop evaporation over land during the twentieth century, J. Hydrometeorol., 12, 823-848, doi:10.1175/2011jhm1369.1, 2011.

Ziolkowska, J. R.: Is Desalination Affordable? - Regional cost and price analysis, Water Resour. Manag., 29, 1385-1397, doi:10.1007/s11269-014-0901-y, 2015. 